\title{
Hail data analyses
}

\author{
Szenteleki K., Gaál, M. \& Ladányi, M. \\ Corvinus University of Budapest, Department of Mathematics and Informatics
}

\begin{abstract}
Summary: Long term data of hail events of three meteorological stations (Budapest, Debrecen and Szeged) were investigated. The hail event frequencies show significant differences in the time period 1901-2000 when the first and the second half of the century are compared. The frequencies of hail events are higher in the first half of the century in case of Debrecen and Szeged while it is higher in the second 50 years for Budapest. None of the frequencies of hail events in between 2001-2008 are significantly higher, though the average of precipitation fell during these events is higher except for Szeged. We have found that the results about the monthly distribution of hail events differ from the ones in the literature; the ratio of hail events is significantly less in the vegetation period.
\end{abstract}

Key words: hail, meteorlogical data, precipitation

\section{Introduction}

In summer 2009 storms and hail events devastated during nearly a month. The Hungarian Meteorological Service alerted during several weeks "orange". Almost the whole country was affected, the damage can be measured in Billions of Forint ( 1 Billion of Forint is more than 3.5 Million Euro): fruits were beaten down, corn, sunflower, oilseed rape fields and also vineyards were seriously damaged.

The agro-damage is estimated as high as 1.1 Billion Forint (cca. 4 Million Euro) in Somogy county (Sonline.hu, 2009) and 6.2 Billion Forint (cca. 23 Million Euro) in Szabolcs-Szatmár-Bereg county (Privátbankár.hu, 2009). One of the most serious damage was in Szabolcs county on the $7^{\text {th }}$ of June; from Tiszavasvári to Beregsurány there was a $20 \mathrm{~km}$ wide strip of land with devastated field of $37000 \mathrm{ha}$ on which $60-100 \%$ of the plants were destroyed.

Against hailstorms anti-hail nets should have significant protection in case of many crops and orchards, but atmospheric hail suppression systems are also successfully used. However, before significant investments, the conditions of the plantation, the applied agrotechnics, the market position of the varieties and the thrift of the investment have to be thoroughly examined (Soltész et al., 2006).

Storms, hail events and other disasters occurred earlier, too, though it is widely accepted that their frequencies and seriousness are getting worse. The reason, however, can be the fact that the same disaster makes more serious damages nowadays because we are having higher level infrastructure. After a disaster, moreover, the rate of publicity is much higher nowadays, too. In our approach we aimed to find out the facts and tendencies of the last more than 100 years.

\section{Materials and methods}

The data were recorded by the Hungarian Meteorological Service (HMS). The daily data of three meteorological stations (Budapest, Debrecen, Szeged) for the time interval 1901-2000 were available. Besides the amount of the precipitation the type of it is also indicated. There are two types distinguished: hail or sleet (ice pellets) and rainstorm with hail. The daily data referring to the time interval 2001-2008-as are coming also from HMS, nevertheless, their coding system is different. We matched hail or sleet with rain with hail and rainstorm with hail with rainstorm with hail.

The size of the hailstones together with the duration of the hail is very important from the damage aspect. The size of the hailstones is usually above 5 millimetres. However, we have no data about the duration of the hail.

\section{Results}

\section{The years in the time interval 1901-2008}

The hail events are not rare in Hungary. Disregarding the spatial and temporal discrepancies, we say that there are about 70-140 days in Hungary with hail events. Szuróczki \& Tókei (1985) estimates the yearly number of hail days at a certain place between 1 and 3. Our data confirmed this in Debrecen and Szeged for the last decades, but the frequencies were higher for the beginning of the last century. The data of the three stations are differentially distributed. There was a long period in Debrecen around the fifties and sixties without hail. The highest frequencies are observed around 1970 and 1980 in Budapest (Figure 1). 
The decreasing order of frequencies (Budapest $>$ Debrecen $>$ Szeged) corresponds to the literature (Bálint, 1967; Szuróczki \& Tökei, 1985; With et al., 1985).

Csury-Marosi (1931) states that there are about 2 years in a decade with serious hailstone damages like in the years 1861, 1869, 1871, 1875, 1880, 1881, 1897 and 1898). Though we do not have data on the rate of damages, we really detected two peaks in most of the decades.

Raum (1910) reckons that the distribution of hail events correlate to the round 11-year cycle of sunspot populations which we could not affirm. The correlation between the number of hail events and the amount of precipitation was the lowest for Budapest. Around 2000 there is a span of time without hail at each station compared to which the events of the recent years seem to be more frequent.

Sütö (2009) analysed hail damage proportions in Hungary's crop production between 1896-2006 based on MABISZ (Association of Hungarian Insurance Companies) information. She distinguished four different periods, where 1967-1990 showed the highest damages. This - and almost the whole curve - shows a high correspondence to the data of Budapest.

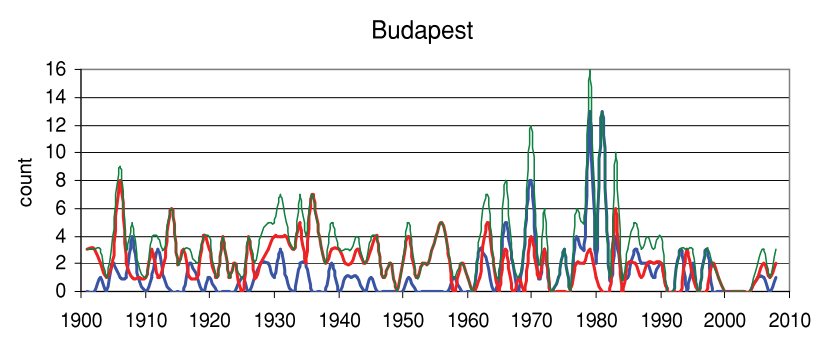

— hail or sleet (6) — rainstorm with hail (9) — total

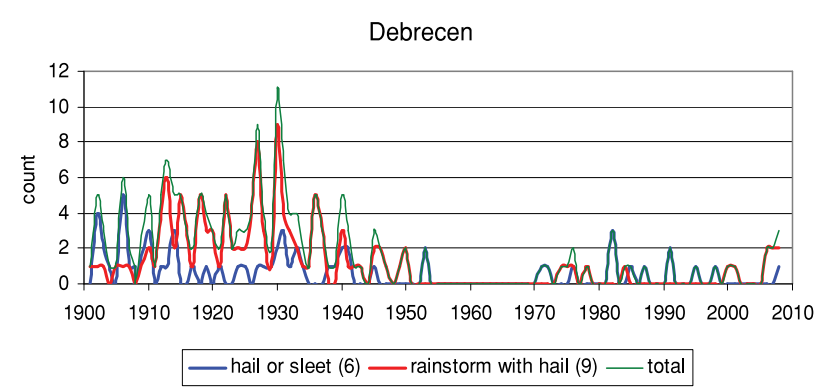

Szeged

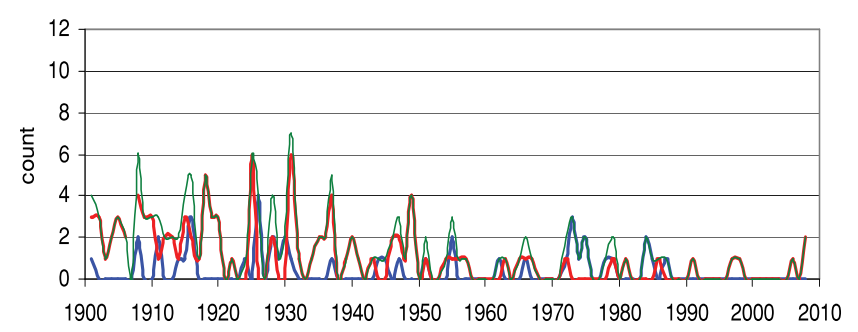

_ hail or sleet $(6)$ _ rainstorm with hail $(9) \ldots$ total

Figure 1: Hail events in the time interval 1901-2008

\section{The decades in the time interval 1901-2008}

The daily data were analysed per decades. The first decade is $1901-1910$ and the last one (the $11^{\text {th }}$ ) contains only 8 years. The differences among the stations we discussed above remain visible while the tendencies are more similar.

Besides the frequencies of hail events the average amount of precipitation fell during the disaster is represented (Figure 2). We can see that high frequencies of hail are coupled with low amount of precipitation which refers to short term events. Nevertheless, there are low frequency periods with high precipitation amounts in the last (truncated) decade in Budapest and Debrecen.

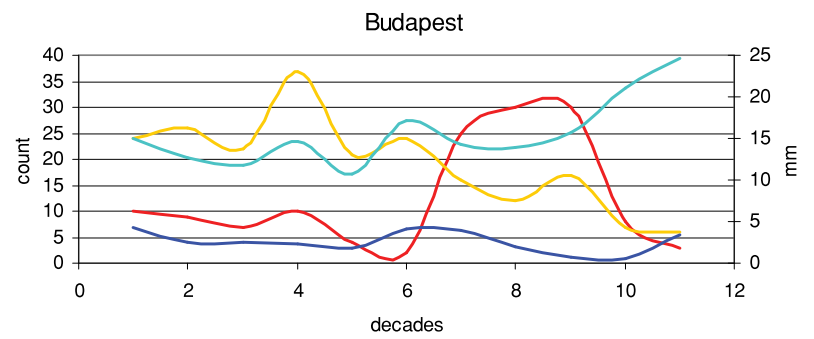

— hail (count) — rainstorm with hail (count) — hail $(\mathrm{mm})$ — rainstorm with hail $(\mathrm{mm})$

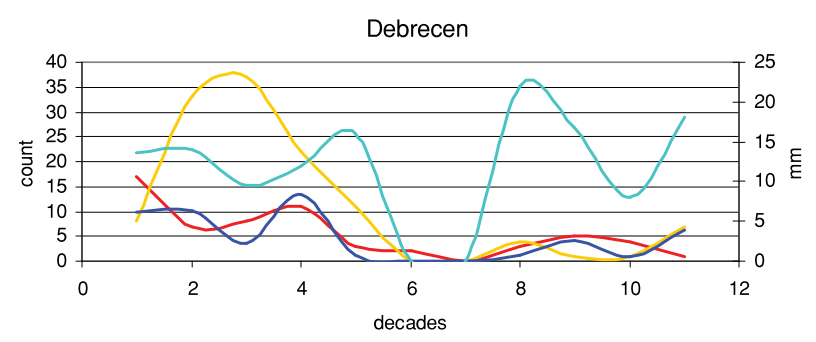

— hail (count) — rainstorm with hail (count) — hail $(\mathrm{mm}) —$ rainstorm with hail $(\mathrm{mm})$

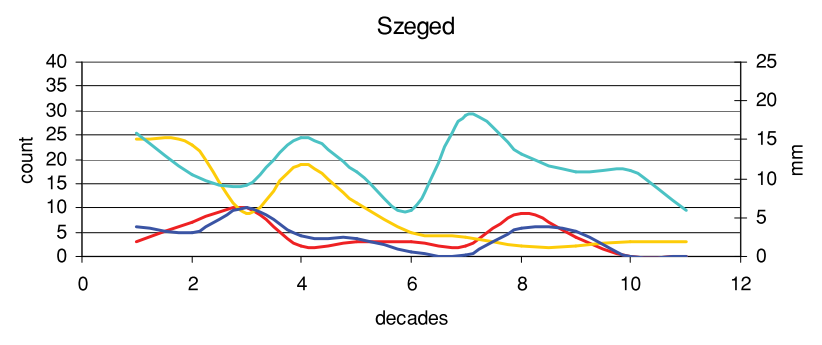

— hail (count) — rainstorm with hail (count) — hail $(\mathrm{mm}) \_$rainstorm with hail $(\mathrm{mm})$

Figure 2: The frequency of hail events and the average amount of precipitation per decades (the last - truncated - decade contains 8 years, only)

\section{The months in the time interval 1901-2008}

The monthly distribution of hail events is under consideration. In the literature the two types of hail (hail/sleet and rainstorm/hail) are mainly not distinguished, we compared them with our summarized ones.

According to the literature, the main part $(90-95 \%)$ of hail events occurs in the vegetation period (between April and September). However, we got different results (Table 1). 
Table 1. The ratio of hail events (\%) in the vegetation period (April to September) (1901-2000, 2001-2008)

\begin{tabular}{|l|c|c|c|}
\hline Hail & $\begin{array}{c}\text { Budapest } \\
56.3 / 66.7\end{array}$ & $\begin{array}{c}\text { Debrecen } \\
81.7 / 0\end{array}$ & $\begin{array}{c}\text { Szeged } \\
74.4 / 0\end{array}$ \\
\hline Rainstorm with hail & $87.9 / 83.3$ & $88 / 85,7$ & $83.3 / 100$ \\
\hline Sum & $75.4 / 77.8$ & $85.9 / 75$ & $80.7 / 100$ \\
\hline
\end{tabular}

\section{Budapest}

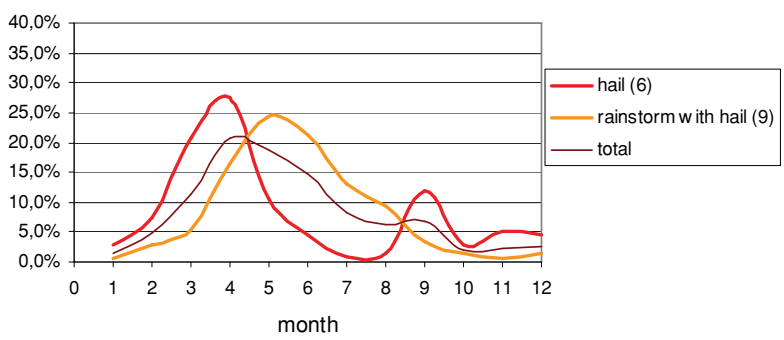

Debrecen

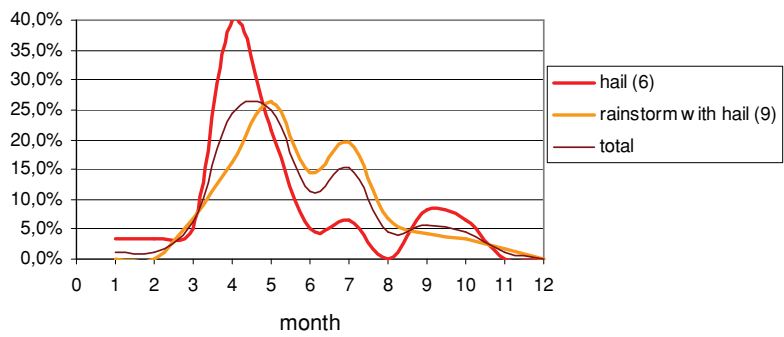

Szeged

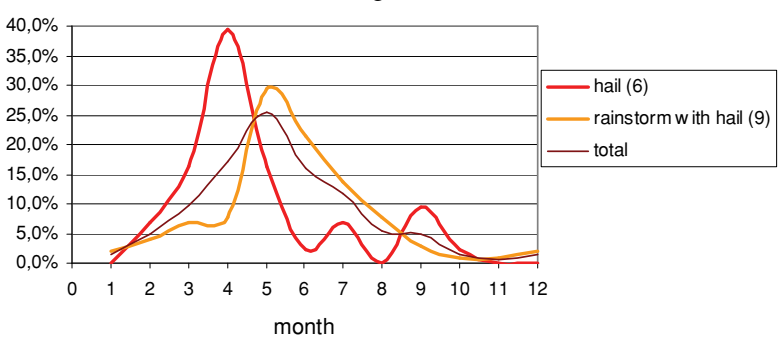

Figure 3: Monthly distribution of hail events (1901-2000)

Moreover, our results contradict to those which state that the most dangerous months are May, June and July (Aujeszky, 1947; Bálint, 1967; Wirth et al., 1985). In the data of time interval 1901-2000 the numbers of hail events are higher in April in every town (Figure 3). The sum of the two types of hail (hail/sleet and rainstorm/hail) is also the highest in April. Nevertheless, the two types of hail have different distribution: the peak of hail/sleet is in March-April with a second (cca. 10\%) one in September. The peak of rainstorm with hail events is in May-June.

\section{Cross tabulation approach}

Let us consider the decades and the months simultaneously. In Figure 4 the monthly distribution of hail events is represented in each decade. The hail events in May-
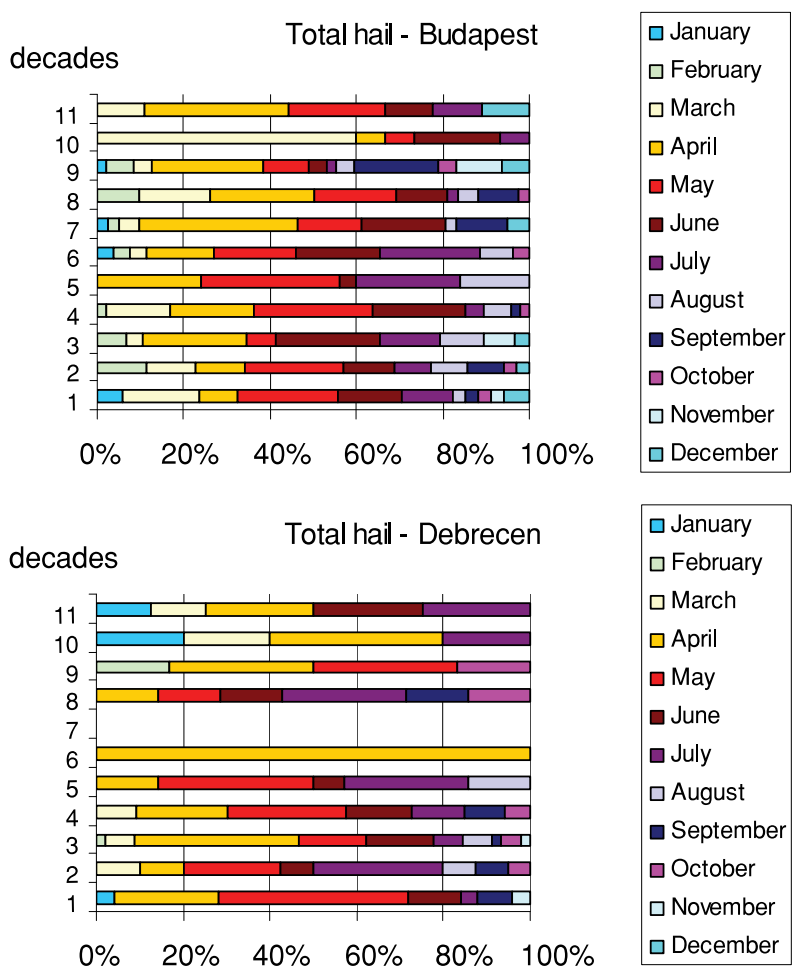

\begin{tabular}{|l|}
\hline$\square$ January \\
$\square$ February \\
$\square$ March \\
$\square$ April \\
$\square$ May \\
$\square$ June \\
$\square$ July \\
$\square$ August \\
$\square$ September \\
$\square$ October \\
$\square$ November \\
$\square$ December \\
\hline
\end{tabular}

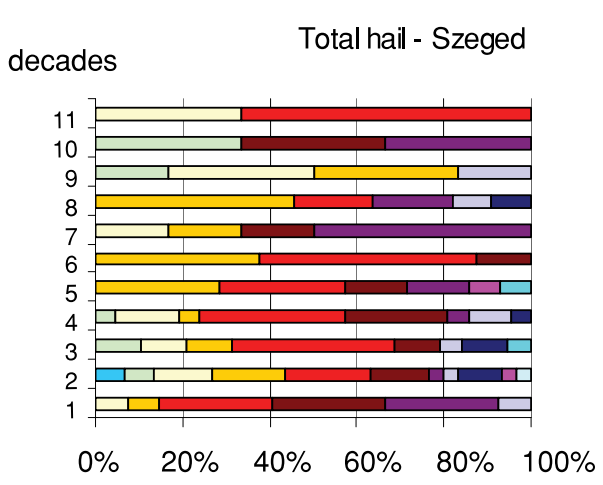

\begin{tabular}{|l|}
\hline$\square$ January \\
$\square$ February \\
$\square$ March \\
$\square$ April \\
$\square$ May \\
$\square$ June \\
$\square$ July \\
$\square$ August \\
$\square$ September \\
$\square$ October \\
$\square$ November \\
$\square$ December \\
\hline
\end{tabular}

Figure 4: The monthly distribution of hail events per decades (1901-2000) (the last - truncated - decade contains 8 years, only)

June in every town were usual in the first decades and in the middle of the century. Nevertheless, there is a detectable realignment in the second half of the century. There are more frequent hail events earlier (in February-March) and later (in August-September).

Note that in the cross tabulation figures $100 \%$ means the total number of hail events in that certain decade. In Figure 5 the frequencies of the observed disasters are represented separately for the two types of hail events. Thus the differences between the decades are more visible in this figure.

Hail and sleet occur mainly in April, though the data of the three stations are quite different. The highest frequencies are in the seventies-eighties in Budapest while the number of spring and fall events increased simultaneously. There were 8 hail events between 1991 and 2000, each of them was in March. The lowest frequencies of hail events can be observed in Szeged where the occurrences are the earliest in the year. In the last two decades there is no data of hail/sleet. 


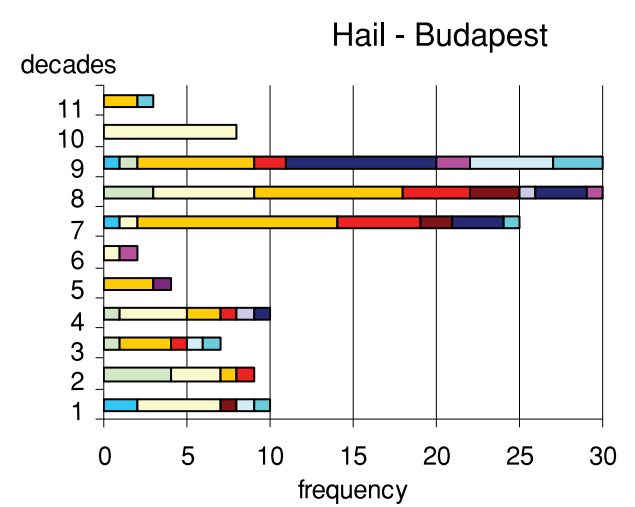

Hail - Debrecen

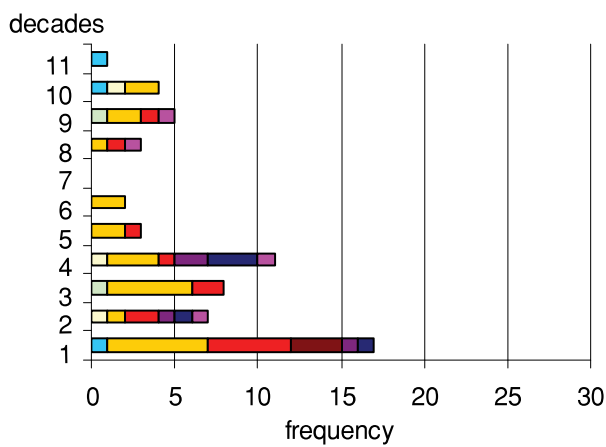

Hail - Szeged

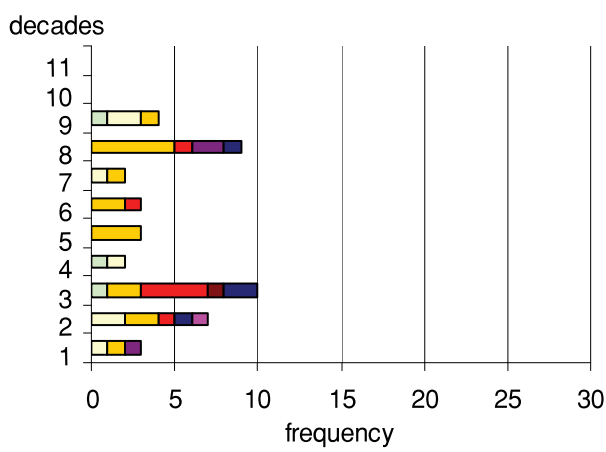

Rainstorm with hail - Budapest

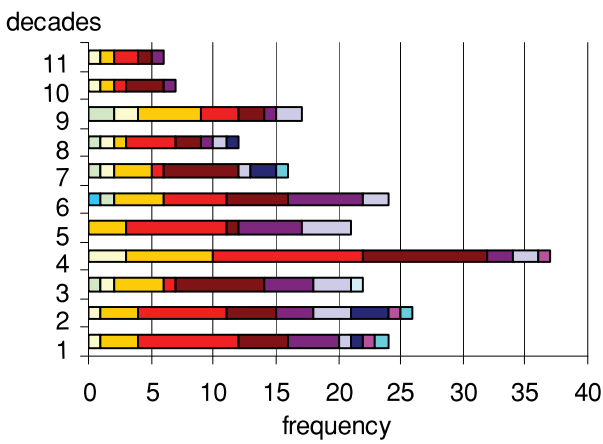

Rainstorm with hail - Debrecen

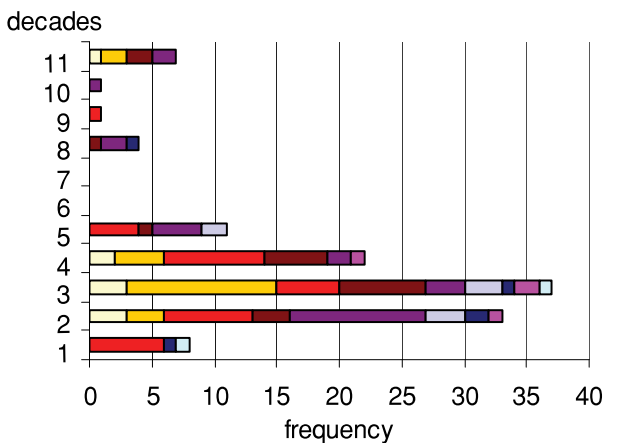

Rainstorm with hail - Szeged

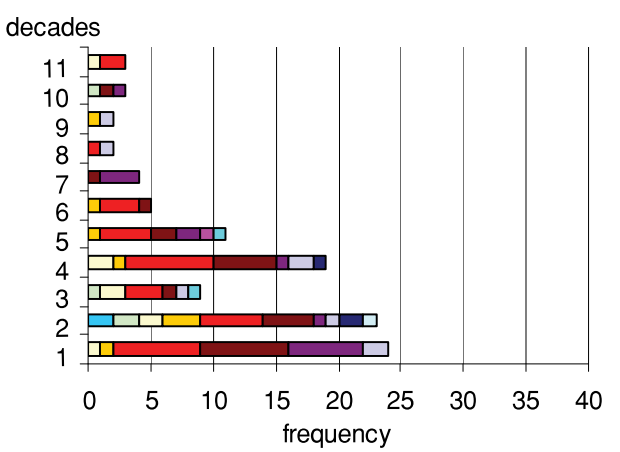

\begin{tabular}{|l|}
\hline$\square$ January \\
$\square$ February \\
$\square$ March \\
$\square$ April \\
$\square$ May \\
$\square$ June \\
$\square$ July \\
$\square$ August \\
$\square$ September \\
$\square$ October \\
$\square$ November \\
$\square$ December
\end{tabular}

Figure 5: The frequencies of hail events, 1901-2008 (the last - truncated - decade contains 8 years, only)

The frequencies of rainstorm with hail events are significantly higher in the first half of the century at all the three stations; the smallest differences can be detected in case of Budapest. The typical month of occurrence is May-July. Note that in 2009 there were hail events in June in Budapest and Szeged which has no yet been represented in our data.

In order to characterize the peaks weighted averages were calculated for the monthly data. However, in case there are two peaks the gained conclusion can be somehow misleading (e.g. Budapest with April and September). If there were equal frequencies for more than one months, the month with higher amount of precipitation was recorded (Table 2).
Table 2. The typical month of hail occurrence (* indicates uncertain characteristics)

\begin{tabular}{|c|c|c|c|c|c|c|}
\hline Decade & $\begin{array}{l}\text { Budapest } \\
\text { hail/sleet }\end{array}$ & $\begin{array}{c}\text { Budapest } \\
\text { rainstorm/hail }\end{array}$ & $\begin{array}{l}\text { Debrecen } \\
\text { hail/sleet }\end{array}$ & $\begin{array}{c}\text { Debrecen } \\
\text { rainstorm/hail }\end{array}$ & $\begin{array}{c}\text { Szeged } \\
\text { hail/sleet }\end{array}$ & $\begin{array}{c}\text { Szeged } \\
\text { rainstorm/hail }\end{array}$ \\
\hline 1901-1910 (1) & 3 & 5 & 4 & 5 & $4 *$ & $6^{*}$ \\
\hline $1911-1920(2)$ & 2 & 5 & 5 & 7 & $3 *$ & 5 \\
\hline 1921-1930 (3) & 4 & 6 & 4 & 4 & 5 & 5 \\
\hline $1931-1940$ (4) & 3 & 5 & $9 *$ & 5 & $3 *$ & 5 \\
\hline $1941-1950(5)$ & 4 & 5 & 4 & $5^{*}$ & 4 & 5 \\
\hline $1951-1960(6)$ & $10^{*}$ & 7 & 4 & - & 4 & 5 \\
\hline $1961-1970(7)$ & 4 & 6 & - & - & $3 *$ & 7 \\
\hline $1971-1980(8)$ & 4 & 5 & $5^{*}$ & 7 & 4 & $8 *$ \\
\hline 1981-1990 (9) & 9 & 4 & 4 & 5 & 3 & $8^{*}$ \\
\hline $1991-2000(10)$ & 3 & 6 & 4 & 7 & - & $6 *$ \\
\hline 2001-2008 (11) & 4 & 5 & 1 & $4 *$ & - & 5 \\
\hline
\end{tabular}




\section{References}

Aujeszky L. (1947): A jégeső gyakoriság és valószínűség Budapesten 1871-1945. Orsz. Met. és Földmágnességi Int. Kiadványai, Bp.

Bálint Gy. (1967): A jégesők és növénytermelésünk jégkárai. Kandidátusi értekezés, Bp.

Csury-Marosi (1931): A magyar biztosításügy története. Szuróczki Z. \& Tőkei L. (1985): Meteorológiai alapismeretek. Kertészeti Egyetem, Bp.

Wirth E., Zakócs J. \& Földvári J. (1985): Jégesők, jégkárok, védekezés, biztosítás. Mezőgazdasági Kiadó, Bp.

Privátbankár.hu (2009): Megint elverte a jégeső Szabolcsot 2009. június 23.
Soltész M., Nyéki J., Szabó Z., Lakatos L., Racskó J., Holb I. \& Thurzó S. (2006): Az éghajlat- és időjárás-változás alkalmazkodási stratégiája a gyümölcstermesztésben. (In: Csete L., Nyéki J. (szerk): Klímaváltozás és a magyarországi kertgazdaság.) "AGRO-21" Kutatási Programiroda, Budapest

Sonline.hu (2009): Milliárdos kárt okozott a jégeső a mezőgazdaságban - 2009. július 14.

Süito Sz. (2009): The role of insurance in the disaster mitigation of fruit orchards. $4^{\text {th }}$ Aspect and Visions of Applied Economics and Informatics, March 26-27, Debrecen, p. 1364-1375. www. avacongress.net/pdf/173.pdf 